\title{
DOES ICT CAPITAL AFFECT ECONOMIC GROWTH IN THE EU-15 AND EU-12 COUNTRIES?
}

\section{Jana HANCLOVA ${ }^{1}$, Petr DOUCEK ${ }^{2}$, Jakub FISCHER ${ }^{3}$, Kristyna VLTAVSKA ${ }^{4}$}

\author{
${ }^{1}$ Department of Systems Engineering, Faculty of Economics, Technical \\ University of Ostrava, Sokolska 33, Ostrava, Czech Republic \\ ${ }^{2}$ Department of System Analysis, Faculty of Informatics and Statistics, \\ University of Economics Prague, W. Churchill sq. 4, Prague, Czech Republic \\ 3, 4 Department of Economics Statistics, Faculty of Informatics and Statistics, \\ University of Economics Prague, W. Churchill sq. 4, Prague, Czech Republic \\ E-mails: 1jana.hanclova@vsb.cz; ${ }^{2}$ doucek@vse.cz (corresponding author); \\ 3ischerj@vse.cz; ${ }^{4}$ kristyna.vltavska@vse.cz
}

Received 21 September 2012; accepted 17 November 2012

\begin{abstract}
The paper examines economic growth in old and new member countries of the European Union (EU-15 and EU-12) during the years of 1994-2000 and 2001-2008 mainly due to changes in information and communication technology (ICT) capital development. The first group EU-15 is presented by old EU countries and the second group EU-12 is presented by new member countries that joined the EU in 2004-2007. The threefactor Cobb-Douglas production function is estimated through the panel general least squares method. The input factors that might influence the economic growth are labour, ICT capital services and non-ICT capital services. Since ICT capital growth data are not available for all selected economies, the groups of countries were reduced to EU-14 and EU-7. The estimated panel production functions confirmed that the average growth of GDP in the EU-7 countries was supported by the stable growth of labour quantity and ICT-capital and increasing total factor productivity. A short-term drop in non-ICT capital growth with follow-up stagnation was caused rather by lower labour productivity. The research discovered that the drop in GDP growth in the EU-14 countries was a result of the slower growth of non-ICT capital and total factor productivity and the stagnated growth of ICT capital with low elasticity, and showed that even the compensation of growth in labour quality did not prevent a decrease in total factor productivity and economic growth.
\end{abstract}

Keywords: ICT capital, economic growth, Cobb-Douglas production function, total factor productivity, panel estimation, panel unit roots tests, EU countries.

JEL Classification: O47, 052, C23.

\section{Introduction}

The impact of information and communication technology (ICT) on economic growth or labour productivity has been already discussed in many papers. Studies from the 1980s focused on this issue in the USA (Jorgenson 2001) and did not confirm any 
significant impact of ICT investments on the so-called productivity paradox. Further research conducted at the state and corporate level rebutted the paradox and confirmed a positive impact of ICT capital. At the corporate level, these investments are linked with other investments in logistics, employee training, etc. and help firms to compete on the market. Therefore, it is not easy to identify all impacts of ICT capital utilization (intensive, extensive). After the year of 2000, many developed countries experienced slower growth of capital, including ICT capital, which led to a short slump in economic growth and especially in labour productivity. As a consequence, production, services and trading in the ICT sector dropped as well.

The goal of the paper is to add to the current literature discussing the impact of ICT capital services on economic growth of national economies and to provide an objective view of this impact with respect to two groups of countries - old and new EU member countries (EU-15 and EU-12) - during the time period of 1994-2000 and 2001-2008. The first group EU-15 is presented by old EU countries and the second group EU-12 is presented by new member countries that joined the EU in 2004-2007 (see Appendix 1).

The paper is organized as follows: Section 1 surveys the empirical literature on the role of ICT capital in economic growth. Section 2 presents the methodological framework of the production function, the estimation method and the verification of a production function model. Section 3 analyzes the economic output and the input factors of the production function. Section 4 implements other dummy variables in an additive and multiplicative form. The panel model of a three-factor production function for the EU-12 group and the EU-15 group is estimated using the panel general least squares method. The obtained results are discussed and compared. The last section concludes the key results of this research study.

\section{The role of ICT in economic and productivity growth}

ICT is a major source of economic growth and labour productivity and is discussed in many papers that interconnect researchers, academicians as well as economic and corporate policymakers.

In 1987, Robert Solow (1987) formulated the productivity paradox (also the Solow computer paradox). It is the peculiar observation made in business process analysis that, as more investment is made in information technology, worker productivity may go down instead of up. Many major studies, especially after the year of 1995, did not confirm this paradox, and it turned out that ICT investments affected the performance of firms, industries and national economies differently, depending on many other factors.

Dedrick et al. (2003) wrote an overview study on the relationship of information and communication technology (ICT) and the economic performance of firms, sectors, national economies and other cross-sectional or panel groups. The authors of the said paper analyzed the results of more than 50 empirical studies from 1985-2002. The first studies from the 1980s and the early 1990s focusing on country-level research showed a non-existing or very weak impact of ICT on economic growth or labour productivity 
growth in the USA (Jorgenson, Stiroh 1995). It was discovered that ICT capital as a share of total capital investment in nominal dollars in th U.S. was 3.5\% in 1980 and 9\% in 1990 (Jorgenson, Stiroh 1995).

However, during the 1990s in the USA, the ICT capital share went considerably up - to $22 \%$ of total capital investment (Dedrick et al. 2003). This ICT revolution was mainly a result of a radical drop in the price of computers, which led to a higher demand of firms and to a substitution of labour with computers (i.e. a considerable increase in the ICT capital share on the total capital of firms). This process from the middle to the end of the 1990s drastically accelerated economic growth as well as labour productivity in the USA and remained in effect during the following years as well. Gross domestic product grew at 3\% per year during 1973-1995 and accelerated to $4.8 \%$ per year in 1995-2000 (Council of Economic Advisors 2001). These conclusions were confirmed by other studies as well. Jorgenson and Stiroh (2000) researched the years of 1973-1999 and concluded that ICT investments contributed to one percent of GDP growth and a half percent of labour productivity growth between 1995-1999.

In their research, economists usually use the growth accounting technique to measure the contribution of production function inputs to an output (economic growth or productivity). The quantitative level of capital and labour factors is differently modified and expanded especially for other determinants of the quality of input factors (e.g. the knowledge and skills of labour, the distinction between ICT capital and non-ICT capital), and the factor of technological progress (the impact of globalization, the impact of R\&D patents) is analyzed in a similar way. The results of empirical studies show that the specific contribution of ICT capital boosts economic growth or labour productivity, in particular through capital deepening and from multifactor productivity growth. In his research, Gordon (2000) also confirmed a major impact of economic cycles on productivity growth in the USA in 1995-2000 while the study of the Council of Economic Advisor (2001) showed a very weak or non-existing impact of economic cycles.

Such extensive studies conducted for the USA have not been repeated for any other national economy. Schreyer's paper (1999) focuses on G-7 countries (the United States, Japan, Germany, Britain, France, Canada, and Italy) during 1990-1996. Schreyer found that ICT made a positive contribution to economic and productivity growth in all seven countries, but the magnitude differed across countries. Another OECD study (Daveri 2000) modified and extended the analysis to 18 OECD and European Union countries during 1992-1997. He concluded that ICT added to GDP growth in the 1990s for all countries studied, but the contribution in EU countries was smaller than in other industrialized countries. Within the EU, differences in ICT contribution growth were also due to lower ICT investment. ICT grew faster than labour input and it contributed to labour productivity through capital deepening. Pohjola's paper (2001) analyzed 39 countries during 1980-1995. He proved that ICT capital stock contributed to economic growth as well as labour productivity growth in developed OECD countries but nothing significant for developing countries. Dewan and Kraemer (2000) researched whether or not this gap was due to the low levels of ICT investment relative to GDP in developing countries, and to the lack of complementary assets for effective use of ICT. They monitored 
36 countries during 1987-1993 and pointed out a positive correlation of ICT investment and labour productivity in developed countries, but not in developing countries. The largest empirical analysis was performed by Kraemer and Dedrick (2001) for 43 developed and developing countries during 1985-1995. They found that growth in ICT investment per worker was positively correlated with labour productivity growth, but the level of ICT investment (in percent of GDP) was not.

Venturini (2009) examines the growth impact for digital capital in the US and the EU-15 countries from a long-run perspective during 1980-2004. He estimated the elasticity of output with respect to ICT within a production function using a panel cointegration analysis. The results showed that ICT capital was a major factor affecting GDP growth especially in connection with the labour productivity revitalization in the 1990s.

Yousefi's paper (2011) represents one of the current empirical results that examine the impact of labour, ICT capital and non-ICT capital input factors on economic growth at the national economy level. The study is based on the classical growth model of the production function, and this model's parameters are estimated for 62 developed and developing countries by using time-series cross-country data for the period of 2000-2006. The results prove that the impact of ICT on economic growth differs across different gross income of countries. The paper concludes that ICT plays a major role in the growth of high and upper-middle gross income, but fails to contribute to the growth of the lower-middle income group countries. These findings support the conclusion that the level of investment in ICT is not the cause of slow growth in lower-middle developing countries as previously thought.

Current research also focuses on the production functions of different sectors within one national economy or across one sector in groups of economies. Karagiannis and Feridun (2009) research the impact of ICT on the output growth of the EU industries in the enlarged European Union (EU-25). They differentiate between the older and new EU member countries - EU-15 and EU-10. In their research, they use the classical Cobb-Douglas production function for 26 industries during 1995-2004. They analyze ICT effects at two different levels - ICT producing industries (i.e. ICT sector outputs, such as the ICT processing industry, ICT trade and ICT services) and industries that make intensive use of ICT (i.e. industries where ICT capital's share on total capital is above average). Their results document that ICT growth performance was generally insignificant in the EU-15 during 1990-1995, but improved substantially during 2000-2004. EU-10 industries have also benefited from the use of ICT, but this impact dropped during 2000-2004. The ICT growth performance was significantly higher in European service industries that make intensive use of ICT.

L. Ruddock and S. Ruddock (2011) focused on the impact of ICT on productivity in the UK construction industry using growth and productivity accounts. They analyzed and measured this effect using data from the EU KLEMS database. The classical input factors of the production function were expanded for capital (ICT and non-ICT) and labour (skill levels) similarly to the publication of Hančlová, Doucek (2011). The results of this analysis provide evidence of steady increase in the growth of ICT and improved labour 
skills usage and a relative high rate of total factor productivity for the UK construction industry. In their paper Lio and Liu (2006) researched ICT adoption in connection with productivity in the agricultural sector in 81 countries during 1995-2000. They concluded that ICT had a major positive impact on productivity in agriculture but, on the other hand, contributes to a divergence among countries.

Two extensive European studies analysing the impact of business ICT solutions on productivity and economic performance revealed positive results on the sample of more than 14.000 EU companies (Dorčák, Delina 2011; Delina, Tkáč 2010). Authors claimed, that the effectiveness of investments into ICT business solutions are specific accoding to type of ICT solutions and the importance is not about the whole amount of investments but the selection of most effective ICT solutions. The study provides the best and most efficient portfolio of ICT business solutions.

In their empirical study Dahl et al. (2011) focused on the impact of ICT on labour productivity growth in Europe after the year of 1995. The obtained results, based on an econometric estimation of the model that utilized multi-country sectoral data, proved a positive and major impact of ICT on productivity growth, in particular through total factor productivity. The impact of ICT in Europe has happened against a negative macroeconomic shock not related to ICT. This is in contrast to the established evidence for the U.S. The authors also noticed a change with respect to previous empirical conclusions in the growth-accounting literature that there has been no acceleration of productivity growth in Europe, mainly due to the dismal performance of ICT using sectors. Some aspects of ICT sector influence on the Czech economy were prestend by Doucek $(2010,2011)$.

Quatraro (2011) also researched whether ICT hardware and services play a complementary role in boosting economic growth. The main argument is that investments in ICT fixed capital are a necessary but not sufficient condition leading to productivity gains, above all in late adopted countries. Their effective implementation indeed requires on the one hand a changing economic structure characterized by a growing weight of services sectors and on the other hand complementary investments in ICT services, directed to ease the integration of the new technologies within a firm's boundaries. He also pointed out that in lagging countries the weak impact of ICT adoption is the result of three converging forces: a relatively high share of manufacturing sectors, low-adoption levels of ICTs in traditional manufacturing sectors and inadequate investments in ICT services.

Hájek and Mihola (2009) analyzed the impact of total factor productivity on economic growth in the Czech economy. They used the two-factor Cobb-Douglas production function of the Czech economy and the method of non-parametric index approach in decomposing the Solow residual. They research the years of 1995-2007, which they divided into two time periods. The main results of this study showed that when the average annual growth rate of real GDP achieved mostly in an intensive fashion had increased by $3.2 \%$, aggregate inputs had gone up only by $0.7 \%$ per year on average while total factor productivity had gone up by $2.5 \%$. A comparison of the trend in 1995-2000 and 2001-2007 showed that the average annual GDP growth rate had gone up from $1.5 \%$ to $4.5 \%$ and that total factor productivity, the average annual growth of which had gone 
up from $1.1 \%$ to $3.5 \%$, had been the major factor of this acceleration. It is necessary to mention that Hájek and Mihola did not work with the recommended labour input, i.e. the number of hours worked, but with the number of persons employed. This issue is also analyzed in detail by Fischer and Sixta (2009), who perform an alternative analysis.

The analysis of these papers shows that the impact of ICT on economic growth or labour productivity has been given a lot of attention. The first studies from the 1980s mainly focused on this issue in the USA and did not confirm the productivity paradox. Further research conducted at the state, sector and corporate level confirmed a positive impact of ICT capital. At the corporate level, these investments are linked with other (supplementary) investments that help firms to compete on the market. However, it is not easy to identify all resources and impacts connected with ICT capital. In 2000, there was a short-term decrease in total capital and ICT capital causing economic growth to decline or stagnate. The following recovery lasted until July 2007 when the mortgage crisis in the USA started, which turned into the economic crisis and brought problems with public finances and the debt crisis. The paper of Rojko et al. (2011) analyzed the impact of the 2008 economic crisis on total expenditures and thus also ICT expenditures. They concluded that the crisis reduced total expenditures and thus also ICT expenditures, but affected the ICT market selectively and also much less than other sectors. The empirical findings indicated that after decades of fast expansion (1990-2000) we are now in a period of slower sectoral growth, which is in line with theories of cycles. The impact of the economic crisis in the ICT segments strongly depends on countries' economic situation and development stage.

\section{The production function with aggregate inputs and methodological framework}

The majority of papers examining the impact of ICT on economic growth use the Cobb-Douglas production function characterized by Hicks-neutral technology $\left(A_{i t}\right)$ and decompose capital input into ICT and non-ICT assets. The exponential form of this production function is as follows:

$$
Y_{i t}=A_{i t} \cdot L_{i t}^{\beta_{1}} \cdot N I C T_{i t}^{\beta_{2}} \cdot I C T_{i t}^{\beta_{3}} \cdot e^{u_{i t}}, \quad i=1,2, \ldots, n, \quad t=1,2, \ldots, T,
$$

where $Y_{i t}$ is real output of economy $i$ in year $t$ (e.g. GDP, added value), input factor is labour input $L_{i t}$ (e.g. the number of hours worked or the number of workers), $I C T_{i t}$ are ICT capital services (including computer hardware, software, telecommunications equipment) and $N I C T_{i t}$ are non-ICT capital services (including non-residential construction, transport equipment and machinery). $A_{i t}$ is a Hicks-neutral total factor productivity in country $(i)$ and in time $(t)$ and $u_{i t}$ are stationary errors.

Under the assumption of perfect competitive factor markets where the marginal product of each input equals its price and constant returns to scale, the above Cobb-Douglas production function (1) can be transformed using the function of natural logarithm $(\ln )$ and the first absolute differences:

$$
\Delta \ln Y_{i t}=\Delta \ln A_{i t}+\beta_{1} \cdot \Delta \ln L_{i t}+\beta_{2} \cdot \Delta \ln N I C T_{i t}+\beta_{3} \cdot \Delta \ln I C T_{i t}+\Delta u_{i t} .
$$


Now we just need to remember that $\Delta \ln X_{t}=\ln X_{t}-\ln X_{t-1}=\ln \left(X_{t} / X_{t-1}\right)$ represents the growth rate of variables $X$ over two studying periods. We can modify the equation (2) as follows:

$$
g Y_{i t}=\alpha_{0}+\alpha_{i t}+\beta_{1} \cdot g L_{i t}+\beta_{2} \cdot g N I C T_{i t}+\beta_{3} \cdot g I C T_{i t}+\varepsilon_{i t}
$$

where $g Y_{i t}$ represents growth in quantity $Y_{i t}$ and $A_{i t}$ growth is broken down to constant $\alpha_{0}$ and fixed effects $\alpha_{\text {it }}$ (a cross-countries ( $i$ ) and period unobservable effect $(t)$ ). We include a common constant term $\left(\alpha_{0}\right)$ so that the fixed effects estimates should be interpreted as deviations from an overal mean. Constant returns to scale of the production function mean that for all regression parameters $0<\beta_{k}<1(k=1,2,3)$ it holds that $\beta+$ $\beta_{2}+\beta_{3}=1$. Regression parameters $\beta_{k}$ express the partial elasticity of output growth in relation to the growth of input factor $k$, ceteris paribus.

The model in the equation (3) will be estimated using the panel general least squares method (PEGLS) with a potential inclusion of fixed effects and with weight correction according to the seemingly unrelated regressions (SUR), which is suited for estimating the parameters of accounting for heteroskedasticity and contemporaneous correlation in the errors across equations (Gujarati 2003).

When verifying the estimated model, the statistical significance of regression parameters, the determination coefficient and the Durbin-Watson statistic (Lukáčiková, Lukáčik 2008) will be monitored. Residual normality will be tested visually, using a histogram and the multivariate Jarque-Bera test (Wooldridge 2010), which tests the skewness and kurtosis of residuals. We will use $F$-statistics to test fixed effects.

Constant returns to scale of the production function will be tested using the Wald test that computes a test statistic based on the unrestricted regression. The Wald statistic measures how close the unrestricted estimates come to satisfying the restrictions under null hypothesis.

According to the Yousefi's paper (2011: 596), a detailed estimation of the production function for the high income group of 28 developed countries (including the EU-15 countries, the Czech Republic and Slovenia - see Appendix 2) is as follows:

$$
g G \hat{D} P_{i t}=\underset{\text { sign. } 0.010}{-1.8325}+\underset{\text { sign. } 0.000}{0.49846} g E_{i t}+\underset{\text { sign. } 0.000}{0.21738} g I C T_{i t}+\underset{\text { sign. } 0.000}{0.19132} g N I C T_{i t} \quad R^{2}=0.408
$$

where $g G D P_{i t}$ is GDP growth in country $i$ and in time $t, g E_{i t}$ is growth in the aggregate employment levels, $g I C T_{i t}$ is growth in ICT expenditure, $g N I C T_{i t}$ is the difference in growth in the gross fixed capital formation and $g I C T$. The estimation of the production function for the upper-middle income group of 17 countries (including Bulgaria, Hungary, Poland, Romania and Slovakia - see Appendix 2) is based on the following equation:

$$
g G \hat{D} P_{i t}=\underset{\text { sign. } 0.352}{-1.7685}+\underset{\text { sign. } 0.059}{0.10297} g E_{i t}+\underset{\text { sign. } 0.061}{0.3485} g I C T_{i t}+\underset{\text { sign. } 0.001}{0.26961} g N I C T_{i t} \quad R^{2}=0.111
$$




\section{Data characteristics and descriptive results}

This study is based on The Conference Board Total Economy Database (The Conference Board 2011). It is a dataset that has been providing indicatory output, input and productivity for 123 countries around the world since 1950. The purpose of this database is to facilitate an international comparison of productivity performance at the macroeconomic level based on consistent and reliable data. The overview paper, which describes this database, including the growth accounting methodology and the construction of the variables, was written by Chen et al. (2010). As mentioned above, the production functions monitor output indicators, and labour and capital divided into ICT capital and non-ICT capital will be used as input factors.

As a measure of output, we will use Gross Domestic Product (GDP), which was obtained from national accounts (OECD National Accounts, Eurostat). The measures of GDP are expressed in constant U.S. dollars market prices for 2010 (in millions), and are adjusted for cross-country differences in the relative prices of goods and services using 2005 purchasing power parity (2005 PPPs).

For the input factor of labour quantity (L), we will use the time-series of total annual hours worked (in thousands) with the original source in OECD National Accounts, OECD Economic Outlook, OECD Employment Outlook and Eurostat.

The input factor of capital will be represented by capital services for two major asset groups - non-ICT capital (including non-residential construction, transport equipment and machinery) and ICT capital (including ICT hardware, telecommunication equipment and software). For each type of asset, a capital stock series $\left(C_{i t}\right)$ is constructed from the investment data $\left(I_{i, t}\right)$. The perpetual inventory method with a geometric depreciation rate is used as follows:

$$
C_{i t}=\left(1-\delta_{i}\right) \cdot C_{i t-1}+I_{i t}
$$

where $\delta_{i}$ is depreciation rate (see Chen et al. 2010: 10). The initial capital stocks $C_{i 0}$ are obtained by assuming initial values equal to $K_{i 0}=I_{i 0} /\left(\delta_{i}+g\right)$ where $g$ is the average GDP growth rate and $I_{i 0}$ is investment in asset type $i$ in the intitial period. Growth in capital services flow in different types of capital stock is:

$$
\Delta \ln C_{t}=\ln C_{t}-\ln C_{t-1}=\sum_{i} w_{i t} \cdot \Delta \ln C_{i t},
$$

where the weights $w_{i t}$ are the average of the shares in period $t$ and $(t-1)$ of each asset type in the value of total capital compensation. The aggregate growth rates of non-ICT and ICT capital services are calculated as the weighted sum of growth rates of individual capital stocks, using the shares in capital compensation. Major data sources for non-ICT investment data are OECD national accounts extended with data from Penn World Tables (PWT). ICT investment data are covered by EU KLEMS extended with WITSA Digital Planet Report 2010. 
The analyzed production functions are compared for two groups of EU countries. The first group EU-12 is represented by new member countries that joined the EU in 20042007. On 1 May 2004, the EU expanded over the following countries: Czech Republic (CZE), Estonia (EST), Cyprus (CYP), Lithuania (LTU), Latvia (LVA), Hungary (HUN), Malta (MLT), Poland (POL), Slovenia (SVN) and Slovakia (SVK). On 1 January 2007, Bulgaria (BGR) and Romania (ROU) joined the EU. Since the time-series of ICT capital growth for CYP, EST, LTU, LVA and MLT are not available, this group will be reduced to EU-7. The second group is represented by "old" EU countries - Austria (AUT), Belgium (BEL), Denmark (DNK), Spain (ESP), Finland (FIN), France (FRA), Great Britain (GBR), Germany (GER), Greece (GRC), Ireland (IRL), Italy (ITA), Luxembourg (LUX), Netherlands (NLD), Portugal (PRT) and Sweden (SWE). This group EU-15 will be reduced to EU-14, since no data on ICT capital growth for Luxembourg are available. The aforesaid database of the input factors and output of the production function was available for EU-7 and EU-14 in 1994-2008. Based on data analysis results and previous empirical research (Dedrick et al. 2011), the researched period was subdivided into two periods: 1994-2000 and 2001-2008.

Figure 1 shows the average annual growth of GDP ( $g G D P$ ) and labour productivity $(g P P)$ (measured by GDP per hour worked). According to Figure 1, labour productivity growth in new EU member countries during 1997-2003 was higher than economic growth. Up until the year of 2000, the average annual growth of GDP was $2.98 \%$, which then accelerated to $4.75 \%$, and we can also see less differentiation among countries. The average annual growth of labour productivity during the first time period was $2.75 \%$ and then $4.09 \%$. In the EU-14 group, labour productivity growth was mostly slower than GDP growth, and this gap was relatively high during 1997-2000 and 2005-2007. Again, the average annual growth of GDP went mostly up until 2000, then slumped until 2003, went back up again and slumped again (all the way to $0.13 \%$ ) after 2007 due to the mortgage, economic and debt crisis. It is obvious that GDP growth in new

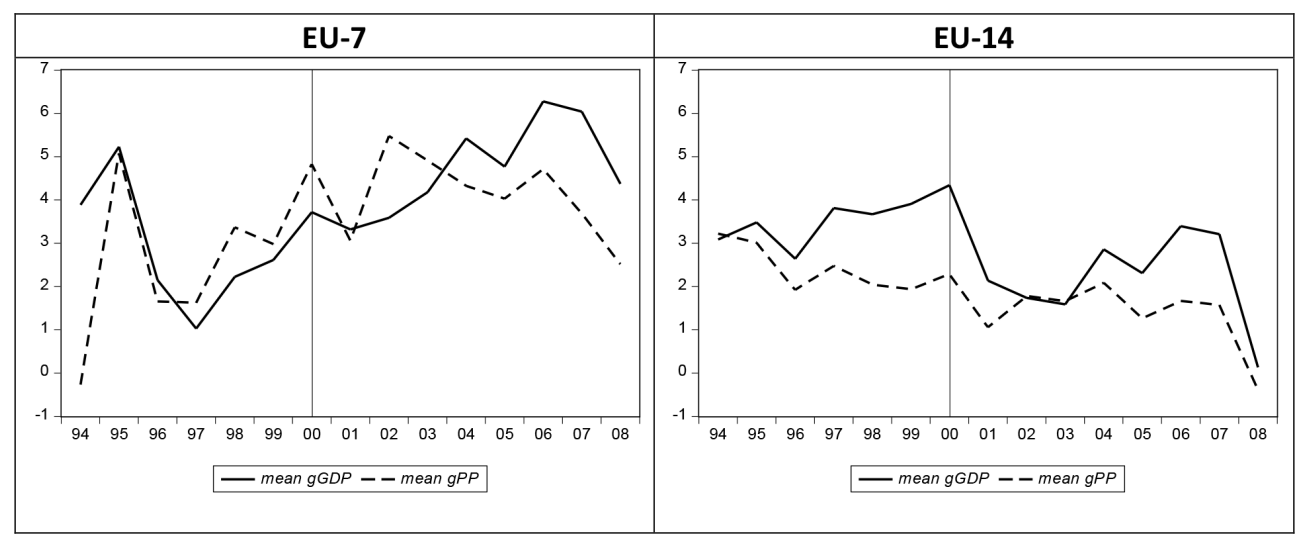

Fig. 1. The mean of GDP and labour productivity growth in the EU-7 and EU-14 countries (in \%)

Source: authors. 
member countries is at a higher level (average annual growth was 3.92\%) and had a relatively high-growing tendency in comparison to the EU-14 group (where average annual growth was $2.82 \%$ and had mostly a declining tendency). Labour productivity growth showed a similar trend, except for the drop in the EU-7 countries at the end of 2008.

Figure 2 shows the growth of output $(g G D P)$ and input factors of the production function - labour $(g L)$, ICT capital $(g I C T)$ and non-ICT capital $(g N I C T)$ - for both groups of countries during 1994-2008.

The average annual growth of labour quantity $(g L)$ in the EU-7 group in Figure 2 shows a drop from $4.15 \%$ to $-1.89 \%$ until the year of 2002 and a following increase to $1.86 \%$ in 2008. ICT capital growth shows mostly an opposite trend; it goes up from $19.66 \%$ to $27.27 \%$ until 1999 , then slumps until 2002 (18.61\%) and after that mostly stagnates around $18 \%$. We should point out the high growth of ICT capital, which fluctuated around $20.72 \%$ per year on average. Non-ICT capital went up from $0.67 \%$ to $3.84 \%$ until 1999, then slightly dropped for a period of four years and, starting in 2004, went up to $5.08 \%$. The EU-14 group shows a growing trend of average growth of output, labour quantity, ICT capital and non-ICT capital, although with different intensity. In 2000-2003, the average annual growth of the quantities dropped and then went slightly up but, in the case of labour quantity and economic growth, was interrupted by the crisis started in 2007 . The average annual growth of ICT capital was $12.93 \%$, which is lower in comparison with the EU-7 group (20.72\%). The growth of non-ICT capital in the EU-14 group, which was $2.42 \%$ per year on average, was also lower than in the EU-7 group where it amounted to $3.44 \%$. On the other hand, the average annual growth of labour quantity in the EU-14 group was higher (0.98\%) as compared to the EU-7 group $(0.45 \%)$.

The principal results of the analyzed time-series of the production function confirm that the ICT revolution in the USA in 1995-2000 (Council of Economic Advisors 2001)

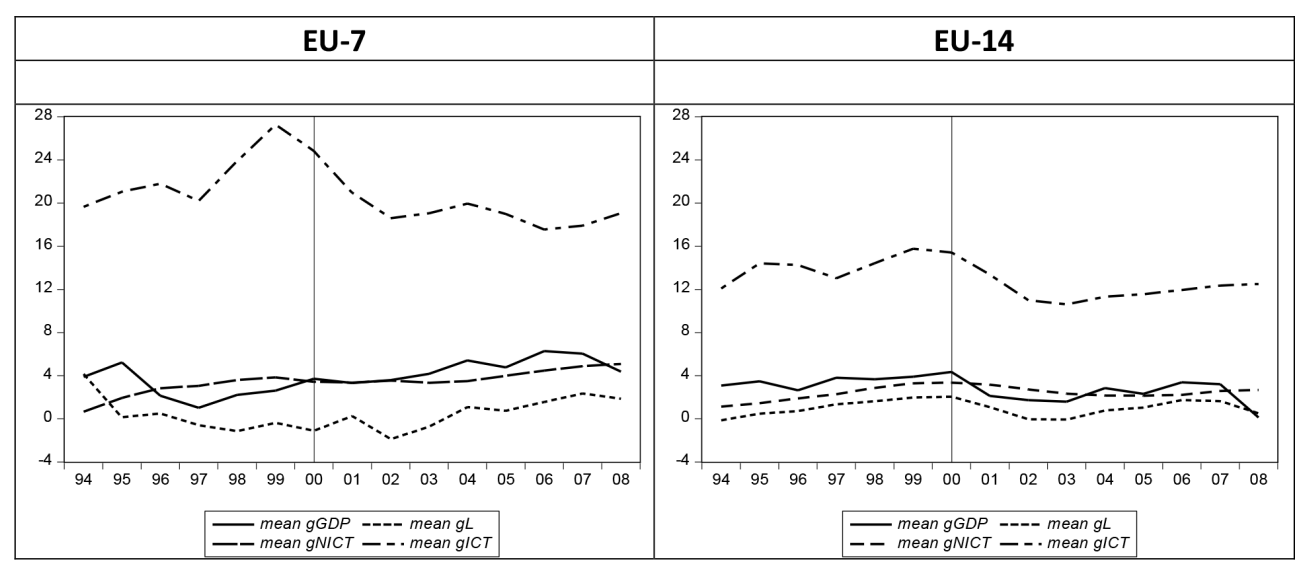

Fig. 2. The mean of the growth of output and input factors of the production function Source: authors. 
Table 1. Probability of ADF panel unit roots tests for examined variables

\begin{tabular}{lllll}
\hline & gGDP & gL & gNICT & gICT \\
\hline EU-7 & 0.0033 & 0.0000 & 0.0000 & 0.0096 \\
\hline EU-14 & 0.0000 & 0.0000 & 0.0000 & 0.0000 \\
\hline
\end{tabular}

Source: authors.

caused the average economic growth of $4.8 \%$ per year. The rise of the "New Economy" resulting from the ITC revolution happened also in the EU countries where it was accompanied with the higher growth of ICT capital (in EU-7 (22.67\% per year)) as compared to EU-14 (14.20\% per year). This process was connected with the slow and long-term growth of GDP in the EU-7 countries until 2007 (3.92\% per year), but in the EU-14 countries this economic growth lasted only until 2000 (3.56\% per year). In both groups of the EU countries, labour quantity in 2000-2001 dropped, which contributed to lower labour productivity because the slower growth of GDP had even a bigger impact $(-2.2 \%)$ than in the case of the decrease in the number of hours worked $(-0.98 \%)$.

In addition to the graphical analysis of time-series, panel unit roots tests were conducted based on the ADF-Fisher Chi-square test with maximum lag length 1 . The obtained probabilities were computed using an asymptotic Chi-square distribution and are shown in Table 1. Null hypothesis: Unit root (assumes individual unit root process) was rejected for all variables included in the table. We can thus say that the panel data are stationary in both groups of countries.

\section{Econometric estimation of production functions}

A dummy variable was implemented for robust estimations of production functions, permitting to monitor the differences in the level constant and the output elasticity with respect to ICT capital for both researched periods. This variable is defined as $D_{i t}=0$ for all countries $i$ during the first period of 1994-2000 and $D_{i t}=1$ otherwise. We will track a change in the level constant using a partial regression parameter for additive dummy variable $D_{i t}$ and a change in the elasticity of the input factors of labour, non-ICT capital and ICT capital using regression parameters for multiplicative variables:

$$
g L_{-} D_{i t}=g L_{i t} \cdot D_{i t}, g N I C T_{-} D_{i t}=g N I C T_{i t} \cdot D_{i t} \text { and } g I C T_{-} D_{i t}=g I C T_{i t} \cdot D_{i t} .
$$

Now we can modify the model formulation (3):

$$
\begin{aligned}
g Y_{i t}= & \alpha_{0}+\alpha_{i t}+\beta_{1} \cdot g L_{i t}+\beta_{2} \cdot g N I C T_{i t}+\beta_{3} \cdot g I C T_{i t}+ \\
& \alpha_{1} D_{i t}+\gamma_{1} \cdot g L_{-} D_{i t}+\gamma_{2} \cdot g N I C T_{-} D_{i t}+\gamma_{3} \cdot g I C T_{-} D_{i t}+\omega_{i t},
\end{aligned}
$$

where the coefficient $\alpha_{0}$ is a common constant term (as a common total factor productivity) and the coefficient $\alpha_{1}$ represents a change in the level constant during 2001-2008 as compared to the time period of 1994-2000. $\left(\alpha_{0}+\alpha_{i t}\right)$ expresses a total factor productivity in country $(i)$ and in time $(t)$ Parameters $\gamma_{k}$ represent a change in the partial elasticity of 
input factor $k$. The panel regression models of the production functions of both groups of countries were estimated using the generalized least squares method with weights obtained from the cross-section seemingly unrelated regression (SUR) in EViews 7.2 software for the time period of 1994-2008.

SUR method is also as the multivariate regression, or Zellner's method, estimates the parameters of the system, accounting for heteroscedasticity and contemporaneous correlation in the errors cross equations. The estimates of the cross equation covariance matrix are based upon parameter estimates of the unweighted system. The test results did not prove any significant fixed effects.

\subsection{Econometric estimation of the production function of the EU-7 countries}

The results of the final version of the estimated model of the production function (9) of the EU-7 countries are summarized in Table 2 where regressor $g L_{-} D, g I C T \_D$ is not included due to its statistical insignificance at $10 \%$ level of significance. The estimated regression parameters of the production function significantly prove that economic growth in the EU-7 countries was positively elastic during the first time period thanks to the quantity of hours worked $(0.093 \%)$, non-ICT capital $(0.381 \%)$ and ICT capital $(0.087 \%)$. All these obtained results are valid, ceteris paribus.

During the second time period of 2001-2008, the level constant increased, which means a higher growth of total factor productivity in the second time period. The elasticity

Table 2. Estimation of the model of the production function of the EU-7 countries

Dependent variable: GGDP

Method: Panel EGLS (Cross-section SUR). Sample: 1994-2008

Periods included: 15; Cross-sections included: 7

Total panel (balanced) observations: 105

\begin{tabular}{lcccc}
\hline Variable & Coefficient & Std. error & t-Statistic & Prob. \\
\hline$g L$ & 0.093323 & 0.050478 & 1.848777 & 0.0674 \\
\hline$g N I C T$ & 0.381110 & 0.057398 & 6.639780 & 0.0000 \\
\hline$g I C T$ & 0.086630 & 0.017701 & 4.893968 & 0.0000 \\
\hline$D$ & 2.201090 & 0.621663 & 3.540648 & 0.0006 \\
\hline$g N I C T \_D$ & -0.266568 & 0.097051 & -2.746679 & 0.0071 \\
\hline Weighted statistics & & & & \\
\hline R-squared & 0.283481 & Mean dependent var & 1.622516 \\
\hline Adjusted R-squared & 0.254820 & S.D. dependent var & 1.326838 \\
\hline S.E. of regression & 1.004905 & Sum squared resid & 100.9834 \\
\hline Durbin-Watson stat & 1.478989 & & & \\
\hline
\end{tabular}

Source: authors. 
of the labour quantity of ICT capital remained the same as in the previous time period and the elasticity of the production function with respect to non-ICT capital decreased by $0.267 \%$, which means that it remained positive $-0.115 \%$. When comparing these conclusions with the other mentioned empirical studies, we can confirm the same partial conclusions, e.g. with Yousefi's paper (2011) from the equation (5) for the upper-middle income group of 17 countries for the estimations from 2000-2006 where the elasticity of the labour factor was $0.11 \%$.

The verification of the estimated model of the production function of the EU-7 countries proves the determination coefficient of 0.283 , which is higher as compared to similar study (Yousefi 2011), where $R^{2}=0.111$. Low level of the coefficient determination is increased on other studies through control variables such as globalization, a labour quality index and R\&D indicators The residual analysis in Figure 3 confirmed residual normality at the 5\% significance level, based on the Jargue-Bera test near the $5 \%$ significance level.

Constant returns to scale were tested using the Wald test with null hypothesis for the first and second time period in the following form:

$$
H_{0}: \beta_{1}+\beta_{2}+\beta_{3}=1 \text { respectively } H_{0}: \beta_{1}+\beta_{2}+\beta_{3}+\gamma_{1}+\gamma_{2}+\gamma_{3}=1
$$

The results of the EU-7 group do not confirm constant returns to scale, which is also documented by probability $<0.000$ in Table 3 , and, according to the sum of estimated regression coefficients, returns to scale of the production function are rather diminishing and less than 1, which is typical for empirical studies in develploping countries (Dedcrick et al. 2011). Due to the low value of the coefficient of determination can be considered introducing of additional control variables (globalization, trade, research) or lagged economic growth into our model in futher research.

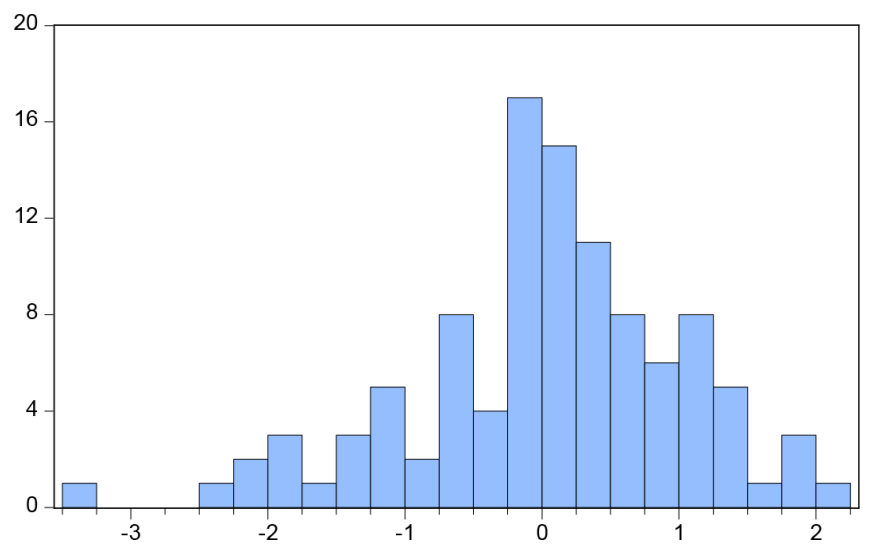

\begin{tabular}{|ll|}
\hline \multicolumn{2}{|l|}{ Series: Standardized Residuals } \\
Sample 1994 2008 \\
Observations & 105 \\
& \\
Mean & 0.041770 \\
Median & 0.122167 \\
Maximum & 2.162612 \\
Minimum & -3.300470 \\
Std. Dev. & 0.984496 \\
Skewness & -0.489589 \\
Kurtosis & 3.614849 \\
& \\
Jarque-Bera & 5.848620 \\
Probability & 0.053702 \\
\hline
\end{tabular}

Fig. 3. Tests of residual normality for the EU-7 countries

Source: authors. 
Table 3. Tests of constant returns to scale of the EU-7 countries

\begin{tabular}{lcccccccc}
\hline & \multicolumn{3}{c}{ Wald test: $1994-2000$} & \multicolumn{5}{c}{ Wald test: $2000-2008$} \\
\hline Test statistic & Value & df & Probability & Test statistic & Value & df & Probability \\
\hline t-statistic & -6.887738 & 100 & 0.0000 & t-statistic & 2.600642 & 100 & 0.0107 \\
\hline F-statistic & 47.44094 & $(1,100)$ & 0.0000 & F-statistic & 6.763338 & $(1,100)$ & 0.0107 \\
\hline Chi-square & 47.44094 & 1 & 0.0000 & Chi-square & 6.763338 & 1 & 0.0093 \\
\hline
\end{tabular}

Source: authors.

\subsection{Econometric estimation of the production function of the EU-14 countries}

The estimation of the production function of the EU-14 group confirmed the same significant impact of ICT capital on economic growth of the EU-14 countries both in 1994-2000 and in 2001-2008. The production function was the most elastic with respect to non-ICT capital $(0.447 \%)$, and in the second time period, dropped by $0.231 \%$, i.e. to the positive level of $0.216 \%$, which is different from the EU-7 group where it was lower $(0.381 \%)$ but stable in 1994-2008. The elasticity of the production function of the EU-14 countries with respect to labour quantity was $0.293 \%$ and considerably higher in comparison to the EU-7 group. During 2001-2008, it went up by $0.245 \%$, i.e. to $0.538 \%$, contrary to EU-7 where it stagnated. The elasticity of the production function with respect to ICT capital was at a similar level (0.032\%), which is comparable with the EU-7 group and remained stable in both researched time periods as well.

When comparing the obtained results with Yousefi's paper (2011) in the equation (4) for the high income group of 28 developed countries (including EU-15, CZE, Slovenia) in 2000-2006, we can say that labour elasticity is comparable (0.499\%) and so is non-ICT capital elasticity $(0.191 \%)$, but this research did not confirm such strong elasticity with respect to ICT capital. This is in compliance with the conclusions of other studies, e.g. Dahl et al. (2011) who say that after 2000, labour productivity did not accelerate due to a decrease in non-ICT capital and ICT capital growth. The results in Table 4 also show a $0.913 \%$ drop, i.e. to $0.758 \%$, in the level constant in 2001-2008, which confirms lower common total factor productivity in the EU-14 countries during the second time period as compared to the years of 1994-2000.

The information value of the estimated production function model of the EU-14 countries was high, with a determination coefficient of 0.910 . The residual analysis confirmed residual normality at the $5 \%$ significance level, which is illustrated by the histogram of standardized residual frequency distribution and the Jarque-Bera test with a probability of 0.112 shown in Figure 4.

Constant returns to scale were tested using the Wald test with the null hypothesis $H_{0}$ $: \beta+\beta_{2}+\beta_{3}=1$. Table 5 summarizes the results for the years of 1994-2000. The null hypothesis for the years of 2001-2008 $H_{0}: \beta+\beta_{2}+\beta_{3}+\gamma_{1}+\gamma_{2}=1$. Table 5 shows that it was not possible to prove constant returns to scale for either researched time period and that the null hypothesis was always rejected at the 5\% significance level, which 
Table 4. Estimation of the production function model of the EU-14 countries Dependent variable: GGDP

Method: Panel EGLS (Cross-section SUR). Sample: 1994-2008

Periods included: 15; Cross-sections included: 14

Total panel (balanced) observations: 210

\begin{tabular}{lcccc}
\hline Variable & Coefficient & Std. error & t-Statistic & Prob. \\
\hline alfa0 & 1.670655 & 0.238576 & 7.002622 & 0.0000 \\
\hline$g L$ & 0.293308 & 0.006611 & 44.36825 & 0.0000 \\
\hline$g N I C T$ & 0.447321 & 0.063070 & 7.092426 & 0.0000 \\
\hline$g I C T$ & 0.031398 & 0.003833 & 8.191163 & 0.0000 \\
\hline$D$ & -0.912701 & 0.227627 & -4.009634 & 0.0001 \\
\hline$g L \_D$ & 0.245076 & 0.025920 & 9.455219 & 0.0000 \\
\hline$g N I C T \_D$ & -0.230572 & 0.075009 & -3.073948 & 0.0024 \\
\hline Weighted statistics & & & & \\
\hline R-squared & 0.909970 & Mean dependent var & & -0.592897 \\
\hline Adjusted R-squared & 0.907309 & S.D. dependent var & & 5.131765 \\
\hline S.E. of regression & 1.003599 & Sum squared resid & & 204.4639 \\
\hline F-statistic & 341.9666 & Durbin-Watson stat & & 2.003230 \\
\hline Prob (F-statistic) & 0.000000 & & \\
\hline
\end{tabular}

Source: authors.

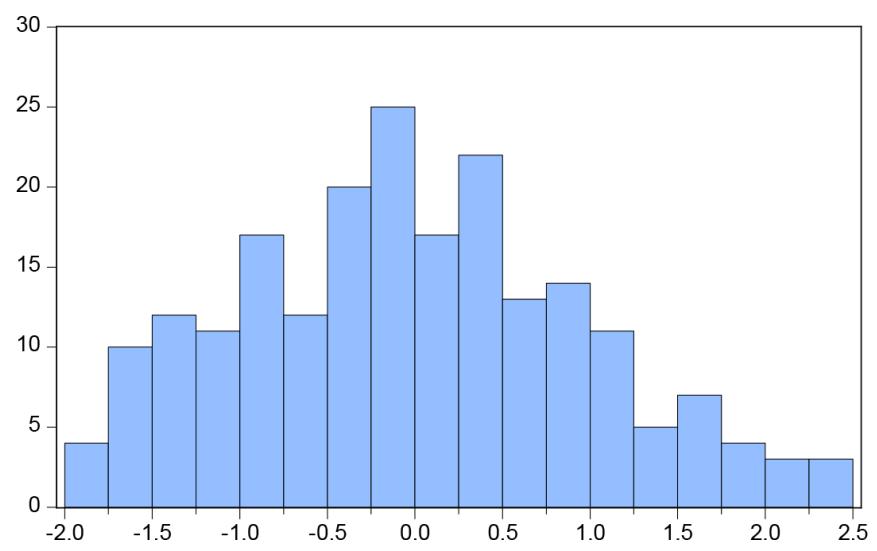

Series: Standardized Residuals

Sample 19942008

Observations 210

Mean $\quad-0.003406$

Median $\quad-0.038418$

Maximum $\quad 2.377014$

Minimum $\quad-1.939727$

Std. Dev. $\quad 0.989083$

Skewness $\quad 0.214703$

Kurtosis $\quad 2.437091$

Jarque-Bera 4.385986

Probability $\quad 0.111582$

Fig. 4. Tests of residual normality for the EU-14 countries

Source: authors. 
Table 5. Tests of constant returns to scale of the EU-14 countries

\begin{tabular}{lccccccc}
\hline \multicolumn{3}{c}{ Wald test: 1994-2000 } & \multicolumn{5}{c}{ Wald test: 2000-2008 } \\
\hline Test statistic & Value & df & Probability & Test statistic & Value & df & Probability \\
\hline t-statistic & -3.388437 & 203 & 0.0008 & t-statistic & -7.331218 & 203 & 0.0000 \\
\hline F-statistic & 11.48150 & $(1,203)$ & 0.0008 & F-statistic & 53.74676 & $(1,203)$ & 0.0000 \\
\hline Chi-square & 11.48150 & 1 & 0.0007 & Chi-square & 53.74676 & 1 & 0.0000 \\
\hline
\end{tabular}

Source: authors.

proves diminishing returns to scale of the production function with respect to the sum of relevant regression coefficients 0.772 for the first time period and 0.787 for the second time period, which is a higher level compared to the group EU-7.

\section{Comparison of results and conclusions}

The compared estimated production function models for both time periods and for the EU-7 and EU-14 groups provide in particular the following conclusions:

- Production function elasticity with respect to labour quantity growth was higher in the EU-14 group during 1994-2000 and went up even more during the following time period, which differs from the EU-7 group where it stagnated.

- Non-ICT capital growth with slightly higher elasticity in the EU-14 group was the most elastic input factor. However, the elasticity of this factor dropped in the following time period by $0.23 \%$ in the EU- 14 group and by $0.27 \%$ in the EU- 14 group, which also led to lower economic growth and labour productivity.

- The impact of ICT capital on total economic growth was proven in both groups of countries, whereas elasticity in the EU-7 group was higher $(0.087 \%)$ than in the EU-14 group (0.031\%). This impact was the same during both researched time periods and thus stable during 1994-2008, although there was a short-term drop after the year of 2000 .

- Total factor productivity (TFP) was analyzed through an estimation and change in the level constant of the production function and it was discovered that in the EU-7 countries, the intercept went up during the researched time periods by $2.20 \%$ while it dropped in the EU-14 countries by $1.67 \%$ to $0.76 \%$.

The obtained results show that in 2001-2008, GDP growth was supported in the EU-7 countries by the stable growth of labour quantity and ICT-capital and increasing total factor productivity. The short-term drop in the growth of non-ICT capital and the follow-up stagnation was caused rather by lower labour productivity.

In the EU-14 countries, the production function analyses in 1994-2008 confirmed that the drop in GDP growth in 2001-2008 was a result of the slower growth of non-ICT capital and total factor productivity and the stagnated growth of ICT capital with low 
elasticity and showed that even the compensation of growth in labour quality did not prevent the decrease in total factor productivity and economic growth.

The obtained results are comparable with similar empirical studies that monitor first the growth of labour productivity mainly in ICT producing industries together with ICT capital deepening and also the acceleration of economic growth after the year of 1995 . ICT capital will be a basic source of GDP growth as well, but rather through the growth of total factor productivity.

Further research should focus on the impact of the analyzed input factors of labour, ICT capital and non-ICT capital on total factor productivity, and these determinants should be expanded for additional supplementary factors, such as the globalization process, R\&D investments, labour quality, the structure of industries, etc. The comparability of obtained results with other studies usually differs, depending on the used database (i.e. the method of measuring and transforming the used input and output quantities of the production function), time period, group of researched countries and production function analysis method (e.g. growth accounting framework, econometric estimations, data envelopment analysis for effectiveness measurement, dynamic stochastic general equilibrium models). It would be also good to examine a more adequate form of the production function, such as transcendental production functions formulated in 1973 by a group of people led by Christensen in the form of translog (transcendental logarithmic) production function.

\section{Acknowledgements}

The paper was supported by the Student Grant Competition of Technical University of Ostrava, Faculty of Economics, within the project SP2012/62, internal projects of University of Economics, Prague: Project No. F4/6/2011 "Measurement of the Contribution of ICT to Competitiveness of the Czech Economy" and project No. 19/2011 "Single-factor and multifactor productivity in context of input-output tables and composite indicators".

\section{References}

Chen, V.; Gupta, A.; Levanon, G.; Ark, B. 2010. Recent productivity developments in the world economy: an overview from the conference board total economy database, International Productivity Monitor 8(19): 3-19.

Council of economic advisors. 2001. The economics of the president-annual report of the council of economic advisors. Washington: U.S. Government Printing Office.

Dahl, Ch. M.; Kongsted, H. Ch.; Sorersen, A. 2011. ICT and productivity growth in the 1990s. Panel data evidence on Europe, Empirical Economics 40(1): 141-164.

http://dx.doi.org/10.1007/s00181-010-0421-4

Daveri, F. 2000. Is growth an information technology story in Europe too?, Working Paper. Parma, Italy: Universita di Parma.

Dedrick, J.; Gurbaxani, V.; Kraemer, K. L. 2003. Information technology and economic preformance: a critical review of the empirical evidence, ACM Computing Surveys 35(1): 1-28. http://dx.doi.org/10.1145/641865.641866 
Dedrick, J.; Kraemer, K. L.; Shih, E. 2011. IT and productivity in developed and developing countries, Working Paper April 2011. Personal Computing Industry Center, Irvine, California. $1-24$.

Delina, R.; Tkáč, M. 2010. The impacts of specific ICT solutions on productivity, in IDIMT: Information Technology - Human Values, Innovation and Economy, 2010. Jindřichův Hradec: J. Kepler University Linz, 23-32. ISBN 978-3-85499-760-3

Dewan, S.; Kraemer, K. L. 2000. Information technology and productivity: preliminary evidence form country-level data, Management Science 46(4): 548-562.

http://dx.doi.org/10.1287/mnsc.46.4.548.12057

Dorčák, P.; Delina, R. 2011. Impact of e-marketing services on economic performance, Ekonomický Časopis 59(1): 44-58.

Doucek, P. 2011. Human capital in ICT - competitiveness and innovation potential in ICT, in G. Chroust, V. Oškrdal, P. Doucek (Eds.). $19^{\text {th }}$ interdisciplinary information management talks IDIMT-2011 - interdisicplinarity in complex systems. Linz: Trauner Verlag universitat, 11-22. ISBN 978-3-85499-873-0.

Doucek. P. 2010. Human resources in ICT - ICT effects on GDP, in G. Chroust, V. Oškrdal, P. Doucek (Eds.). $18^{\text {th }}$ interdisciplinary information management talks - IDIMT-2010 information technology - human values, innovation and economy. Linz: Trauner, 97-105. ISBN 978-3-85499-760-3.

Fischer, J.; Sixta, J. 2009. Towards the measurement of total factor productivity index, Politická Ekonomie 57(4): 544-554.

Gordon, R. 2000. Does the "new economy" measure up to the great inventions of the past?, Journal of Economic Perspectives 14(4): 49-76. http://dx.doi.org/10.1257/jep.14.4.49

Gujarati, D. N. 2003. Basic econometrics. New York: McGraw-Hill.

Hájek, M.; Mihola, J. 2009. Analysis of total factor productivity contribution to economic growth of the Czech Republic, Politická Ekonomie 57(6): 740-753.

Hančlová, J.; Doucek, P. 2011. Education and ICT sector in the EU (Panel-National Application), in R. Kvasnicka (Ed.). Efficiency and responsibility in education 2011. Prague: Czech University of Life Sciences Cambridge, 84-92. ISBN 978-80-213-2183-0.

Jorgenson, D. W. 2001. Information technology and the U.S. economy (Presidential address to the American Economic Association), American Economic Review 91(1): 1-32.

http://dx.doi.org/10.1257/aer.91.1.1

Jorgenson, D. W.; Stiroh, K. J. 1995. Computers and growth, Economics of Innovation and New Technology 3(4): 295-316. http://dx.doi.org/10.1080/10438599500000008

Jorgenson, D. W.; Stiroh, K. J. 2000. Raising the speed limit: U.S. economic growth in the information age, Brookings Papers on Economic Activity 1(1): 125-211.

http://dx.doi.org/10.1353/eca.2000.0008

Karagiannis, S.; Feridun, M. 2009. Growth effects of information and communication technologies: empirical evidence from the enlarged EU, Transformation in Business \& Economics 8(2): 86-99.

Kraemer, K. L.; Dedrick, J. 2001. Information technology and productivity: results and implications of cross-country studies, in M. Pohjola (Ed.). Information technology and economic development. Cambridge: Oxford University Press, 242-256.

Lio, M. C.; Liu, M. C. 2006. ICT and agricultural productivity: evidence from cross-country data, Agricultural Economics 34(3): 221-228. http://dx.doi.org/10.1111/j.1574-0864.2006.00120.x

Lukáčiková, A.; Lukáčik, M. 2008. Ekonometrické modelovanie s aplikáciami. Bratislava: Ekonóm. 
Pohjola, M. 2001. Information technology and economic growth, in M. Pohjola (Ed.). Information technology and economic development. Cambridge: Oxford University Press, 257-279.

Quatraro, F. 2011. ICT capital and services complementarities: the Italian evidence, Applied Economics 43(20): 2603-2613. http://dx.doi.org/10.1080/00036840903299805

Rojko, K.; Lesjak, D.; Vehovar, V. 2011. Information communication technology spending in (2008-) economic crisis, Industrial Management Data Systems 11(3-4) 391-409. ISSN 02635577. http://dx.doi.org/10.1108/02635571111118279

Ruddock, L.; Ruddock, S. 2011. ICT and agricultural productivity: evidence from cross-country data, Agricultural Economics 34(3): 221-228. ISSN 0169-5150.

Schreyer, P. 1999. The contribution of information and communication technology to output growth, Statistical Working Paper No. 99:4. OECD, Paris. ISSN 1815-1965.

Solow, R. 1987. We'd better watch out, New York Times Book Review July 12: 36.

The Conference Board. 2011. The Conference Board Total Economy Database (TED), January 2011 [online], [cited 24 July 2012 ]. Available from Internet:

http://www.conference-board.org/data/economydatabase/.

Venturini, F. 2009. The long-run impact of ICT, Empirical Economics 37(3): 497-515.

http://dx.doi.org/10.1007/s00181-008-0243-9

Wooldridge, J. M. 2010. Econometric analysis of cross section and panel data. Cambridge, Massachusetts: The MIT Press. ISBN 978-0262232586.

Yousefi, A. 2011. The impact of information and communication technology on economic growth: evidence from developed and developing countries, Economics of Innovation and New Technology 20(6) 581-596. ISSN 1043-8599. http://dx.doi.org/10.1080/10438599.2010.544470

\section{Appendix 1}

The first group EU-12 is represented by "new" member countries that joined the EU in 2004-2007. On 1 May 2004, the EU expanded over the following countries: Czech Republic (CZE), Estonia (EST), Cyprus (CYP), Lithuania (LTU), Latvia (LVA), Hungary (HUN), Malta (MLT), Poland (POL), Slovenia (SVN) and Slovakia (SVK). On 1 January 2007, Bulgaria (BGR) and Romania (ROU) joined the EU. Since the time-series of ICT capital growth for CYP, EST, LTU, LVA and MLT are not available, this group will be reduced to EU-7.

The second EU-15 group is represented by "old" EU countries - Austria (AUT), Belgium (BEL), Denmark (DNK), Spain (ESP), Finland (FIN), France (FRA), Great Britain (GBR), Germany (GER), Greece (GRC), Ireland (IRL), Italy (ITA), Luxembourg (LUX), Netherlands (NLD), Portugal (PRT) and Sweden (SWE). This group EU-15 will be reduced to EU-14, since no data on ICT capital growth for Luxembourg are available.

\section{Appendix 2}

The list of the whole group of 28 developed countries:

Source: Yousefi Ayoub (2011: 596) - Appendix 2 Income groups by World Bank.

The list of 28 developed countries (i.e. high income group in 2006): Australia, Austria, Belgium, Canada, Czech Republic, Denmark, Finland, France, Germany, Greece, Hong 
Kong (China),Ireland, Israel, Italy, Japan, Korea Rep., The Netherlands, New Zealand, Norway, Portugal, Saudi Arabia, Singapore, Slovenia, Spain, Sweden, Switzerland, the UK, US.

The list of 17 developing countries (i.e. upper-middle income group in 2006): Argentina, Brazil, Bulgaria, Chile, Costa Rica, Hungary, Malaysia, Mexico, Panama, Poland, Romania, Russian Federation, Slovak Republic, South Africa, Turkey, Uruguay, Venezuela $(\mathrm{RB})$.

Jana HANCLOVA, PhD, she is an Associated Professor of econometrics at Technical University of Ostrava, Faculty of Economics, Department of Systems Engineering. Currently she is a president of the Czech Society of Econometrics. She is also a member of the Czech Economic Society and the Czech Society for Operational Research. She has been a member of the expert commissions of the Czech Science Foundation for several years. She is a co-author of 10 monographs, 13 papers in the specialized journals and 59 articles in the conference proceedings. Her research priorities have included investigation of structure, dynamics and disparities in the regional labor markets and at present she focuses mainly on macro-econometric modeling of the EU economies.

Petr DOUCEK (Prof.), PhD, heads the Department of System Analysis at University of Economics, Prague. His main topics in research and development work focus on information management, IS/ ICT security management, project management and impacts of information society on human. $\mathrm{He}$ published 13 monographs, 74 articles in reviewed journals and presented more than 100 contributions on international conferences.

Jakub FISCHER, PhD, graduated at the University of Economics, Prague, in 2001 (Statistics and Insurance) and attained a PhD degree in statistics in 2005. In 2008 he has become an Associate Professor of statistics. Since 2008 he is a head of the Department of Economic Statistics. He is focused on the field of social and economic statistics and national accounting. He solves several research projects. $\mathrm{He}$ is a member of the Czech Statistical Society, Czech Demographic Society, a member of the Board of the Czech Economic Society and a member of the Academic Assembly of the Czech Academy of Science. He is an author of co-author of 4 monographs, 30 articles and 75 conference papers.

Kristyna VLTAVSKA, PhD. She is a lecturer at the Department of Economic Statistics, University of Economics, Prague. She focuses on the estimation of labor productivity and total factor productivity with reflection of new input variables to the production function (labor services, capital services) and the influence of the quality of dataset on the quality of the estimate. She is the author of several scientific studies and conference papers. 